\title{
INFERÊNCIA METAFÍSICA E A EXPERIÊNCIA DO OBSERVÁVEL
}

\author{
ANJAN CHAKRAVARTTY
}

\begin{abstract}
Some strongly empiricist views of scientific knowledge advocate a rejection of metaphysics. On such views, scientific knowledge is described strictly in terms of knowledge of the observable world, demarcated by human sensory abilities, and no metaphysical considerations need arise. This paper argues that even these views require some recourse to metaphysics in order to derive knowledge from experience. Central here is the notion of metaphysical inference, which admits of different "magnitudes", thus generating a spectrum of putative knowledge with more substantially empirical beliefs at one end, and more metaphysically imbued beliefs at the other. Given that metaphysical inference is required even concerning knowledge of the observable, the empiricist hope of avoiding metaphysics altogether is futile: knowledge of the observable simply involves metaphysical inferences that are of smaller magnitudes than others. Metaphysical inferences are required not only to distinguish veridical from non-veridical experience and to determine the quality of empirical information, but also in order to explain how we construct experience (through categorizations and classifications of objects, events, processes, and properties), how we extrapolate from empirical evidence to generalize about observable phenomena, and how we use this evidence to test and confirm hypotheses and theories.
\end{abstract}

Keywords: Scientific knowledge; empiricism; experience; metaphysics; metaphysical inference.

\section{O observável, o inobservável e a ciência}

Em diferentes ramos da filosofia, o termo "experiência" é usado como um rótulo para uma variedade de coisas diferentes. Na filosofia da ciência - especialmente em conexão com debates epistemológicos sobre como teorias e modelos científicos são mais bem interpretados como produzindo conhecimento do mundo - tal rótulo tipicamente tem uma aplicação estrita para detecções de aspectos do mundo por meio de modalidades sensoriais humanas sem ajuda. Nesse contexto, qualquer tipo de detecção envolvendo o uso de (digamos) instrumentos científicos em adição aos nossos sentidos, como microscópios e contadores Geiger, é colocada fora dos limites da experiência per se. Temos a experiência de imagens e movimentos de ponteiros que aparecem em nossos instrumentos, é claro, pois os observamos usando nossos sentidos sem ajuda. Mas as entidades que são supostamente detectadas pelo uso de tais instrumentos não são experienciadas — ao menos, não de acordo com essa convenção terminológica. Coisas que são objeto da experiência dessa maneira (para especificar novamente, de uma maneira comum entre filósofos, se não entre cientistas) são observáveis, e coisas que não são experienciáveis assim são inobserváveis. De

Principia 21(2): 189-207 (2017).

Published by NEL — Epistemology and Logic Research Group, Federal University of Santa Catarina (UFSC), Brazil. 
posse dessas convenções linguísticas, posso agora revelar o assunto deste artigo: a natureza da nossa experiência do mundo observável da investigação científica. ${ }^{1}$

Poderíamos nos perguntar que valor haveria em adotar um tema tão estreito, tratando apenas de experiências a respeito de fenômenos observáveis que são objetos de interesse, estudo e finalmente predição e explicação nas ciências. Afinal, não há dúvida de que no processo da investigação científica temos experiência de uma vastidão de objetos, eventos, processos e propriedades. Poderíamos, então, pensar se não é também o caso que tentamos sondar além deste mundo de experiência, em direção a fenômenos inobserváveis que subjazem ao mundo observável, de modo a gerar as predições e explicações que são características das ciências? E será que não é o caso que essa sondagem além é o que há de mais interessante e importante a respeito da investigação científica?

Esse tipo de questão é o pão com manteiga das discussões sobre o realismo e o antirrealismo científicos - a saber, discussões entre aqueles que pensam que nossas melhores teorias e nossos melhores modelos trazem conhecimento do inobservável e aqueles que desconfiam dessa ideia, ou que a acham pouco atraente. Não é minha intenção contribuir diretamente com essas discussões aqui, mas, dito isso, é certo que há uma dimensão do debate realismo/antirrealismo que é relevante para a motivação deste artigo. Os realistas científicos têm a tendência de acreditar em uma coleção maior de proposições sobre o mundo (em virtude de acreditar em supostos fatos sobre entidades inobserváveis revelados pelas ciências) do que seus interlocutores antirrealistas. De fato, um princípio antirrealista comumente levantado é para que tenhamos mais cautela ao circunscrever o escopo razoável de crenças. Isso é especialmente pertinente aos presentes propósitos.

Historicamente, muitos antirrealistas científicos defenderam uma ou outra forma de empirismo bastante estrito, isto é, formas de empirismo que defendem limitações do conhecimento produzido pelas ciências ao conhecimento do mundo observável. Aqui temos o fenomenalismo de Ernst Mach, o convencionalismo de Henri Poincaré a respeito da natureza do espaço e do tempo, o instrumentalismo dos primeiros trabalhos de Albert Einstein e as variadas posições associadas ao empirismo lógico. Essas são compreensões da ciência que ligam a ideia de conhecimento científico a concepções sobre a experiência. E um tema comum entre muitas dessas abordagens estritas do empirismo (usarei simplesmente o termo "empirismo" daqui em diante, tendo em mente essa conotação de ser estrito) é que um entendimento adequado do nosso conhecimento científico do mundo é aquele que se caracteriza pela ausência de especulação metafísica. Isso quer dizer que se o conhecimento em questão é entendido de maneira estrita, como deveria ser, em termos da experiência do mundo observável, e sendo que o observável é demarcado pelo uso de nada mais que as modalidade sensoriais humanas, então nenhuma consideração metafísica precisa entrar na aquisição de conhecimento.

Principia 21(2): 189-207 (2017). 
O que eu pretendo mostrar abaixo é o pensamento de que mesmo se tomarmos esse tipo de abordagem ao conhecimento científico, em que os limites e escopos razoáveis do conhecimento são demarcados pela experiência, ainda assim há recurso inevitável à metafísica ao entender no que esse conhecimento resulta. Isso não implicará que todos que interpretam os outputs epistêmicos das ciências em diferentes maneiras, incluindo variedades de realistas e antirrealistas científicos, estejam saturados com metafísica no mesmo grau. O que sustentarei é que tipicamente realistas científicos fazem o que chamarei "inferências metafísicas" em uma proporção maior do que os empiristas antirrealistas. De fato, é possível expandir essa moral para muito além do contexto argumentativo dos debates sobre o realismo e o antirrealismo científicos. Por exemplo, alguns realistas e antirrealistas consideram certos tópicos que são de interesse da metafísica acadêmica (concebida como um sub-ramo da filosofia), como teorizações sobre a natureza dos mundos possíveis e das substâncias, relações ostensivamente primitivas como a fundamentação, relações mereológicas e assim por diante, como sendo divagações fantasiosas, em oposição a investigações genuínas a respeito da natureza do mundo. Em disputa nesses casos, assim sustentarei, estão questões a respeito da compatibilidade de certos graus de inferência metafísica com a produção de conhecimento.

Embora uma apreciação da noção de "magnitudes" de inferência metafísica poderia, penso eu, iluminar toda sorte de diferença de atitude epistêmica em relação a diferentes maneiras de teorizar sobre a natureza da realidade, ${ }^{2}$ meu objetivo primário no que segue será argumentar que inferências metafísicas sobre o conhecimento do observável são exigidas mesmo para o empirista, e não apenas na interpretação dos outputs da ciência, tais como teorias e modelos. Na próxima seção, elucidarei a ideia de inferências metafísicas e os sentidos em que elas admitem "graus", tendo portanto diferentes "magnitudes". Na seção 3, de modo a preparar o terreno para minha conclusão a respeito da inevitabilidade da inferência metafísica mesmo no que diz respeito à experiência, revisarei algumas discussões lendárias da história da filosofia sobre a relevância ou irrelevância da metafísica na ciência e mostrarei como, apesar do pedigree dessas discussões, elas são amplamente inconclusivas. Na esperança de fazer melhor na conexão com o observável, a seção 4 considerará diversas maneiras pelas quais, afinal de contas, nossa experiência do mundo das ciências inevitavelmente recorre à inferência metafísica. Finalmente na seção 5 apresentarei duas considerações finais a favor dessa conclusão, obtidas e inspiradas pela história da filosofia da ciência.

Se o leitor é um empirista e não consegue, neste ponto, deixar a impressão ranzinza de que deveríamos preferir evitar a metafísica toda de uma vez, a perspectiva de uma tal conclusão pode parecer desagradável ou até mesmo repelente. Não é minha intenção, no entanto, ser do contra. A moral que está por vir, como eu vejo, não é um repúdio ao empirismo como tal, porém um apelo por um entendimento de nuances 
do empirismo em continuidade com abordagens menos restritivas à interpretação do conhecimento científico; todas essas abordagens exigem inferência metafísica em algumas formas e em alguns graus de modo a construir imagens coerentes do mundo. Dessa forma, a moral a seguir não deve ser recebida como má notícia, mas apenas como a oferta de alguma iluminação geral sobre a condição epistêmica humana pelo menos, assim eu sugiro.

\section{Inferências metafísicas, em princípio e na prática}

O que poderia significar dizer que a produção de conhecimento do mundo observável por meio da experiência pode ser feita sem metafísica, ou que para ter esse conhecimento precisamos de pelo menos alguma metafísica? Em vista do desafio familiar de definir o que exatamente é metafísica em termos outros que aqueles muito abstratos, é possível imaginar o que se quer dizer com "metafísica" neste contexto em particular. Em princípio, é possível dizer que afirmações sobre o que existe e sobre como são essas coisas - que é o tipo de afirmação gerada pelas ciências — são afirmações sobre ontologia, e a ontologia é um ramo da metafísica. Assim, todas as inferências a respeito desse tipo de afirmação, incluindo o subconjunto relevante delas que é produzido pelas ciências, envolvem inferências metafísicas. Acredito que há alguma coisa nisso - existe alguma verdade nisso. Mas colocar dessa forma é muito apressado e, de qualquer forma, francamente pouco convincente. É pouco convincente em parte porque parece insinuar que as ciências podem ser vistas simplesmente como um ramo da metafísica (como os filósofos concebem). Mas deveríamos considerar isso uma tolice: na melhor das hipóteses, é fácil demais; na pior, é obviamente falso. Para extrair o sentido em que mesmo afirmações sobre observáveis nas ciências envolvem inferências metafísicas é preciso decifrar um pouco.

Na prática, o termo "metafísica" é usado de maneiras muito diferentes em contextos diferentes e, consequentemente, é regularmente aplicado a tipos muito diferentes de inferências. Os empiristas lógicos, por exemplo, descreviam crenças sobre inobserváveis científicos, tais como partículas subatômicas e sequências de genes, como metafísica, mas os realistas científicos tipicamente não concordam com esse uso e, no entanto, eles acreditam que inferências sobre esse tipo de coisa são adequadamente descritas dessa maneira, como metafísica. Por outro lado, alguns realistas científicos usam o temo "metafísico" para descrever assuntos que vão além do que eles tomam como temas centrais da investigação científica, o que inclui partículas, genes e por aí vai. Esses assuntos que "vão além" dos temas centrais podem incluir tópicos que são mencionados no discurso científico, mas apenas de passagem, tais como a natureza das leis científicas, ou das propriedades, ou da modalidade (necessidade, contingência e possibilidade). Esses tópicos, muitos diriam, são realmente metafísicos. Isso sem mencionar todos os outros tópicos listados acima em conexão

Principia 21(2): 189-207 (2017). 
com a "metafísica acadêmica", os quais têm pouca chance de aparecer, ainda que de passagem, no discurso científico, embora sejam, ainda assim, predominantes nas salas de aula dos metafísicos.

Como entender essas diferentes aplicações do termo "metafísica" na prática? Eu entendo que todas essas crenças e inferências relacionadas a respeito do que existe e de como são essas coisas são metafísicas. O que permite essas diferentes práticas de atribuir rótulos não é algo substantivo a respeito dos assuntos relevantes enquanto ontologia. Em lugar disso, as diferentes práticas de atribuir rótulos são indicativas de algo completamente diferente: o fato aparentemente banal de que a maioria das pessoas, tanto filósofos quanto cientistas, não gosta de usar o termo "metafísica" em relação a afirmações ontológicas para as quais elas pensam que temos forte evidência ou garantia epistêmica. Contudo, essa banalidade a respeito de como as pessoas frequentemente se expressam disfarça um ponto com grande peso filosófico. As pessoas com frequência preferem não usar o termo "metafísica" em conexão com coisas em que elas pensam que têm garantia para crença, porque na fala comum (o uso cotidiano da língua natural) o termo é regularmente, e às vezes exclusivamente, associado à conotação de ser excessivamente especulativo, talvez até místico ou oculto. E, é claro, aquilo que é excessivamente especulativo, em virtude disso ser uma coisa ruim, não é suficientemente fundamentado em evidência convincente a ponto de merecer crença. E agora se revela o ponto filosoficamente substantivo: existe um equívoco aqui. Como vou sugerir a seguir, a noção de que é excessivamente especulativo não está no objetivo de quando se fala cuidadosamente sobre a inferência metafísica na filosofia.

O processo de fazer inferências metafísicas — partir de dados ou premissas em direção a conclusões à maneira característica da metafísica - tem uma dimensão a priori importante. Em outras palavras, é um processo que é abastecido principalmente, ou em larga medida, por considerações não empíricas, em oposição a considerações empíricas ou a posteriori, essas últimas sendo aquelas que são diretamente informadas por, ou especialmente sensíveis a, dados da experiência. As considerações amplamente não empíricas envolvidas nas inferências metafísicas são tipicamente explicativas, o que quer dizer que elas frequentemente envolvem deliberações sobre como otimizar os tipos de características que são comumente associadas a boas explicações. Assim, àqueles que estão abertos a tal deliberação, uma boa inferência metafísica é geralmente concebida como aquela que traz uma boa explicação dos dados, de acordo com critérios que incluem a simplicidade, a consistência interna, a coerência com o conhecimento de fundo e o escopo dos fenômenos que ela unifica. O caráter a priori desse raciocínio é exibido de diversas maneiras: com frequência, procede-se, por exemplo, ao analisar nossos conceitos e ao tomar seriamente nossas intuições a respeito de como diversas virtudes explicativas, como essas que acabam de ser mencionadas, devem ser ponderadas.

Principia 21(2): 189-207 (2017). 
Entretanto, como demonstra a comparação rascunhada acima entre diferentes práticas de atribuir rótulos envolvendo "metafísica", uma coisa é esclarecer o que exatamente é uma inferência metafísica, e outra coisa bastante diferente é produzir acordo sobre se exemplos específicos são vistos adequadamente como metafísica. Diagnostiquei essa falta de acordo em termos de um equívoco, e agora é possível expressar a ambiguidade inerente a essa situação de maneira ainda mais econômica: em geral, as inferências que produzem afirmações ontológicas são, defendo, inferências metafísicas no sentido que acabei de esboçar em termos do papel assumido por considerações a priori no processo de fazê-las; distante disso, em reação a uma conotação de falta de garantia que pertence a um contexto de discussão estritamente distinto, agentes epistêmicos geralmente se abstêm de descrever afirmações ontológicas como metafísica quando eles se sentem justificados. A moral que quero extrair aqui é que decisões sobre se certa afirmação ontológica pode ser caracterizada como metafísica são, na prática, distinguíveis da questão sobre se há, de fato, inferências metafísicas envolvidas na produção de tais afirmações. Em princípio, tendo em vista o que descrevi como inferências metafísicas, o que temos aqui é simplesmente um amplo domínio delas, caracterizadas na prática como instâncias de metafísica, ou não, conforme o caso, por diferentes agentes epistêmicos.

Dito isso, devemos reconhecer, por respeito ao empirista, que algumas inferências metafísicas estão "mais próximas" do que outras do fundamento da evidência empírica. A metáfora da proximidade à evidência empírica - e de maneira correlata, de estar mais longe ou mais além de tal evidência — admite a possibilidade de uma análise mais fina do que a que tenho espaço para fazer aqui (veja a nota 2). Contudo, o alcance da metáfora para os propósitos presentes deve (espero) agora estar claro. Trazendo um pouco da terminologia introduzida acima, há o que podemos descrever como graus de inferência metafísica, avaliados de acordo com a proximidade que se nota que a prática inferencial em questão tem em relação a, no sentido de ser informada por ou de ser sensível a, dados empíricos. De posse dessas clarificações a respeito da natureza da inferência metafísica, devemos nos voltar agora à tese mais central e mais controversa deste artigo: a ideia de que mesmo na menor ponta do espectro de afirmações a respeito da ontologia científica, onde se está tão perto do fundamento da evidência empírica a ponto de as afirmações sobre o que há e sobre como essas coisas são serem restritas a afirmações sobre o mundo observável, não há como escapar da inferência metafísica.

\section{Debates inconclusivos sobre metafísica na ciência}

Neste ponto, os leitores que já contemplaram questões sobre a natureza do conhecimento científico e da metafísica podem estar tendo a experiência completamente

Principia 21(2): 189-207 (2017). 
razoável de um déjà $v u$. A questão sobre se a metafísica tem algum lugar na, ou em relação à, ciência é uma velha conhecida da história da filosofia. Para que essa não seja uma questão fácil demais para responder, é preciso restringir seu escopo ao domínio das ciências modernas, excluindo os modos anteriores de se investigar o mundo, tais como as diversas tradições históricas sob o estandarte da filosofia natural, no qual o que reconheceríamos hoje como métodos científicos e filosóficos (entre outros) estavam fundidos juntos e era difícil separá-los. A ciência mais recente, feita após a ruptura entre os domínios profissionais da ciência e da filosofia, apresenta-se como um caso menos óbvio; como consequência, não é de se surpreender que tenha havido sérios debates sobre as relações possíveis entre ciência e metafísica nesse período. É importante perceber, como defenderei agora, que esses famosos debates são inconclusivos, exceto como motivação para a visão positiva da inevitabilidade da inferência metafísica que busco oferecer. Assim, vejamos primeiro a situação desses debates tradicionais.

Para começar, por um lado, existe a linhagem lendária de pontos de vista que assumem uma concepção antimetafísica da ciência. As críticas mais minuciosas da ideia de que a metafísica pode ser relevante para as, ou conectada às, ciências modernas são naturalmente associadas às várias formas de filosofia empirista e instrumentalista. Os dois campos sustentaram que qualquer investigação sobre a ontologia do mundo que busque produzir ou que ostensivamente produza conhecimento de entidades inobserváveis (objetos, eventos, processos e propriedades) é, por isso, metafísica. Porém, tendo em vista que, como essas posições argumentaram com alguma força, é um erro conceber as ciências em termos desses objetivos ou em termos da suposta produção de tais conhecimentos, o pensamento de que a metafísica possa ter qualquer relação que seja com o empreendimento científico é, na melhor das hipóteses, uma confusão e, de qualquer forma, um engano. De acordo com essas abordagens sobre a natureza da ciência, a experiência sensorial sem ajudas delimita o domínio real e adequado do conhecimento científico e isso efetivamente fecha a porta para qualquer metafísica intrusa. A metafísica é concebida como uma forma de investigação tenta alcançar além do domínio do observável.

É certo que há muitas críticas específicas a versões específicas das abordagens instrumentalistas e empiristas às ciências que poderíamos apresentar. Essas são bem conhecidas e não há necessidade de discuti-las aqui em profundidade. O empirismo lógico levantou significativa preocupação a respeito do critério de significado verificacionista, de acordo com o qual a ausência de um procedimento empírico que possa verificar ou confirmar uma proposição supostamente factual implica que ela é estritamente desprovida de significado e, assim, deve ir para a pilha de lixo da metafísica. A preocupação de muitos era que, na qualidade de uma proposta para determinar o que conta como tendo significado, o próprio verificacionismo faz parte da metafísica — ou então é indefensável exceto por recurso a princípios metafísicos. Além do fato 
de que esta história é bem conhecida, há outra razão para não mergulhar mais profundamente nos detalhes aqui. Concepções instrumentalistas e empiristas do conhecimento científico formam uma família mais ampla de visões do que compromissos tão específicos como o verificacionismo permitiriam identificar. Compromissos mais específicos desse tipo são importantes historicamente, mas, pela mesma razão, são idiossincráticos a formulações particulares dessas visões, em oposição a ingredientes necessários das posições relevantes mais amplamente concebidas. É possível deixar de lado esses compromissos problemáticos e ainda assim manter um compromisso mais geral ao instrumentalismo ou ao empirismo.

Portanto, concedendo o benefício da dúvida a uma concepção apropriadamente ampla dessas tradições filosóficas, vamos dirigir nosso foco para uma preocupação mais geral que pareceria relevante a abordagens empiristas e instrumentalistas ao conhecimento científico, mesmo que se formulem tais abordagens de maneira mais precisa. À primeira vista, temos a impressão de que as ciências estão transbordando de inferências metafísicas, pois a maioria das ciências assume o que parece ser um interesse sério com toda forma de entidade inobservável hipoteticamente subjacente aos fenômenos observáveis que cientistas detectam; eles tentam articular essas entidades por meio de teorização, experimentação, modelagem e simulações. Se aceitarmos essas formas de prática científica pelo seu valor aparente, é difícil ignorar o que parece óbvio - que os cientistas rotineiramente parecem estar estudando, ou tentando estudar, coisas tais como forças eletrostáticas, estruturas proteicas, taxas de inflação, o nível de depressão clínica nas sociedades, e todo tipo de coisa que não é passível de detecção apenas por meio das modalidades sensoriais humanas. Com base nesses fatos aparentemente óbvios sobre a prática científica, poderíamos nos preocupar com o fato de que por meio da eliminação de inferências a respeito da existência e da natureza de coisas inobserváveis — isto é, por meio da eliminação das inferências metafísicas — os instrumentalistas e empiristas estejam fazendo uma extraordinária redescrição dos evidentes objetivos e sucessos da investigação científica.

Assim sendo, se alguém estiver equipado para revelar que as aparências superficiais de alguma prática humana são enganosas e que a concepção correta dessa prática é algo que possa, de fato, ser revelado pela análise filosófica cuidadosa, então talvez haja trabalho aqui para a filosofia. Nesse espírito, tomemos seriamente o diagnóstico empirista das descrições superficiais da teorização, modelagem, etc., da ciência como uma descrição do que essa prática realmente é - a saber, um elaborado sistema de investigação que serve finalmente para produzir apenas conhecimento do observável. Mesmo aceitando tudo isso, uma dificuldade permanece. O diagnóstico empirista é exaurido numa concepção do conteúdo do conhecimento científico em termos do mundo observável da experiência, mas presta pouca atenção aos meios pelos quais esse conhecimento é produzido. Isto é, tal ponto de vista falha ao se 
ocupar de maneira séria com a onipresença da inferência metafísica. Insinuei acima que enquanto as magnitudes das inferências metafísicas particulares são variáveis, a própria inferência metafísica é difícil de evitar se queremos interpretar as ciências como indicando conhecimento de alguma forma em relação ao que existe no mundo, mesmo no mundo da experiência. ${ }^{3}$ Se isso estiver correto, então, mesmo que os empiristas estejam certos sobre que o conhecimento científico é mais bem concebido como conhecimento do observável, eles estão errados em descrever essa concepção das ciências como isentas de metafísica, pois isso exigiria que sacrificassem a maior parte do, se não todo o, conhecimento que consideram que a ciência gera.

Talvez alguns empiristas estejam dispostos a pagar esse preço surpreendentemente alto. Sem dúvida, com um pouco de engenhosidade, é possível imaginar versões do fenomenalismo, ou do idealismo, ou do solipsismo, em que esse preço é pago, uma vez que, ex hypothesi, nessas formulações imaginadas, não há afirmação de qualquer pretensão de conhecimento a respeito de uma realidade distinta dos pensamentos ou experiências dos seres humanos. É por essa razão, no fim, que os debates em torno da tradicional defesa empirista e instrumentalista de que as ciências são francamente isentas de metafísica podem se mostrar inconclusivos - já que isso estimularia os apetites dos empiristas pelo que seria, da perspectiva de boa parte da filosofia contemporânea, um excesso ou então formulações pouco atraentes do empirismo. Mesmo assim, essas formulações podem se provar portos seguros para um empirista obstinado.

Passemos agora à visão inteiramente oposta de que, de fato, as ciências modernas incorporam aspectos do pensamento metafísico. Mais uma vez, não é difícil encontrar pronunciamentos nesse sentido ao longo da história da filosofia. Porém, a maioria dessas declarações têm como objeto de estudo pretendido a filosofia natural no contexto do início do período moderno. No entanto, apesar de talvez menos comum, não é raro encontrar filósofos que expandam tais declarações ao período das ciências modernas. Considere, por exemplo, a defesa de Thomas Kuhn (1962[1970]) de que os compromissos metafísicos são um componente inextricável dos numerosos compromissos compartilhados pelos membros de uma comunidade científica, os quais juntos compõem o paradigma ou os paradigmas que governam suas ciências. De comprometimentos a certos padrões de prática autêntica da ciência, tais como formas aceitáveis de explicação (e.g., teleológica, mecanicista, causal), até suposições de certos princípios axiomáticos básicos que servem de base para a pesquisa, esses compromissos são simplesmente parte da ciência relevante. Na fonte de um trabalho mais recente sobre o tema da ciência e da metafísica, variações dessa ideia se tornaram um tema. A seguinte expressão disso, de Craig Callender (2011, p.48), pode ser tomada, penso eu, como um resumo representativo:

[O] que chamamos convencionalmente de ciência em assuntos comuns é

Principia 21(2): 189-207 (2017). 
inextricavelmente infundido com a metafísica de alto (teoria) a baixo (experimento). A metafísica é profundamente importante para a ciência. Desnudar os pressupostos metafísicos de nossas melhores teorias do mundo é uma parte crucial e importante da compreensão do mundo.

Considerando que virar a mesa é jogo limpo, assim como anteriormente levantei uma preocupação bastante geral sobre a tese empirista de que não há metafísica aqui de que se possa falar, agora levantarei uma preocupação bastante geral a respeito de outra ideia, a de que a metafísica permeia toda a ciência. Essa última preocupação surge do desafio de determinar, de alguma maneira definitiva, se diversos candidatos a compromisso metafísico são, de fato, considerados genuinamente ou devidamente metafísicos em uma reflexão mais cuidadosa. Quando confrontados com exemplos concretos, muitas vezes é difícil concluir com uma confiança razoável que os compromissos relevantes não são, afinal de contas, empíricos de maneira significativa. Esse tipo de ambivalência decorre da dificuldade de julgar até que ponto o que se poderia considerar como conteúdo metafísico é, de fato, isolado de considerações empíricas, de modo que sua classificação como a priori possa ser considerada razoável ou adequada. Esse desafio é mais bem ilustrado no contexto de casos específicos. Examinemos brevemente, então, alguns exemplos para apreciar quão rapidamente as atribuições de conteúdo metafísico podem se tornar inconclusivas.

O físico norte-americano Robert Millikan é, com razão, famoso por ter realizado uma série de experimentos no início do século $X X$ cuja ambição era determinar a magnitude da unidade fundamental da carga elétrica. Millikan suspendeu gotículas ionizadas de óleo entre duas placas carregadas; ao ajustar a tensão elétrica entre as placas, ele conseguiu alterar a força do campo elétrico ambiente de modo a contrariar a força da gravidade sobre as partículas. Usando a equação de Stokes, ele então calculou o valor de sua carga e concluiu finalmente que todos os resultados eram múltiplos integrais de uma quantidade específica: (aproximadamente) 1,602 $\times 10^{19}$ Coulomb. Ele sugeriu então essa quantidade de carga como a unidade fundamental. Entretanto, na mesma época em que Millikan estava realizando suas experiências, o físico austríaco Felix Ehrenhaft estava realizando experimentos semelhantes usando minúsculas esferas de metal em vez de gotículas de óleo, e seus resultados indicavam medidas cada vez menores de carga elétrica, o que ele considerou apoiar a conclusão muito diferente de que não há uma tal quantidade fundamental.

Em sua discussão sobre a disputa que se seguiu, Barry Barnes, David Bloor e John Henry (1996, cap.2) argumentam que Millikan e Ehrenhaft tinham diferentes pressupostos de fundo e, como consequência, produziram e interpretaram seus dados de maneira contrária. É muito bem possível ver esses pressupostos como metafísicos. No meio científico de Millikan, a ideia de que certas quantidades são quantizadas, admitindo apenas magnitudes discretas, fez um estardalhaço, atraindo muita atenção como uma heurística fértil para a física da época. Por outro lado, Ehrenhaft estava 
comprometido com a noção rival de que essas quantidades são contínuas; a carga, por exemplo, seria algo que deveria ser descrito em termos de um fluido ou campo elétrico contínuo. Citando uma análise dos cadernos de Millikan (onde ele registrou suas observações experimentais) feita pelo historiador da ciência Gerald Holton, Barnes et al. argumentam que diferentes interpretações dos experimentos eram possíveis: Millikan aceitou certas observações e descartou outras de maneiras que favoreceram sua suposição de que a carga elétrica é quantizada e admite uma menor quantidade possível. Mas agora levantemos algumas dúvidas sobre se a suposição atribuída é devidamente vista como metafísica. Com o passar dos tempos, com mais trabalhos experimentais e outros desenvolvimentos na física, a história acabou favorecendo Millikan. Será que sua suposição está adequadamente caracterizada como a priori, ou será que deveria ser considerada, ao invés disso, como uma hipótese empírica que foi finalmente justificada pela evidência?

Para ilustrar o ponto em outro domínio, passemos da física fundamental de um século atrás para o trabalho contemporâneo em biomedicina. J. A. Marcum (2005) traça o desenvolvimento da pesquisa do câncer nas últimas décadas, sugerindo que essa área tem sido dominada por dois pressupostos metafísicos conflitantes. O primeiro, que ele chama de "reducionismo", manifesta-se comumente como uma versão do determinismo genético, a ideia de que, geralmente, os estados e processos biológicos podem ser explicados (por isso "reduzidos") em termos de genes e atividade genética. No lado oposto, há o que ele chama de "organicismo", um rótulo para a visão de que os fenômenos emergentes em níveis superiores de organização biológica são, de fato, cruciais para as explicações dos fenômenos em níveis mais baixos. Neste contexto particular, uma abordagem organicista pode explicar a produção de células cancerosas (por exemplo) ligando-a causalmente a certas formas de organização de tecido anormal. Novamente, espelhando os diagnósticos das hipóteses quântica e contínua de Millikan e Ehrenhaft, respectivamente, é possível pensar que o determinismo genético e o organicismo na pesquisa sobre câncer exemplificam algum conteúdo genuinamente metafísico. Certamente, reducionismo e emergentismo são alguns dos temas favoritos do debate metafísico. Com um pouco de reflexão, porém, é possível questionar se os pressupostos relevantes são adequadamente considerados como metafísicos, em oposição a considerá-los hipóteses empíricas que são testadas ao longo do tempo no curso da pesquisa.

A função dessa rápida revisão de argumentos familiares da história da filosofia, segundo a qual as ciências modernas são em grande parte livres ou, ao contrário, repletas de metafísica, é mostrar sua fragilidade. Por um lado, as negações empiristas das inferências metafísicas nas ciências modernas podem ser difíceis de sustentar (como agora tentarei demonstrar de forma mais definitiva), sob pena de recuar para formas de empirismo que são impopulares atualmente. Por outro lado, pode haver a preocupação de que muitas vezes não está claro se o que parece inicialmente ser 
uma premissa metafísica pode ser distinguido de hipóteses empíricas, pois, nos casos reais, uma mesma coisa pode ser descrita de forma plausível de uma ou de outra maneira. Considero que esses debates tradicionais são inconclusivos e é por essa razão que não contarei com eles para tirar conclusões sobre a inferência metafísica na ciência. Como mencionei, acredito que a ideia de que a inferência metafísica é inescapável na construção do conhecimento científico é correta. Isso, no entanto, deixa aberta a questão sobre como entender melhor essas inferências metafísicas em conexão com as visões que focalizei aqui especificamente, a saber, visões que restringem esse conhecimento ao mundo observável da experiência. Voltemos a essa questão agora.

\section{Inferência metafísica na experiência do observável}

Comecei este ensaio notando que não é incomum para filósofos inclinados a certas formas de empirismo sustentar que a metafísica é totalmente desnecessária para uma concepção adequada das ciências. Se fosse assim, evitaríamos inteiramente o que descrevi aqui como o espectro da inferência metafísica. Entretanto, essa visão empirista é, penso eu, equivocada. É mais exato, e, portanto, melhor, dizer que se pretendemos restringir o conhecimento científico do mundo ao conhecimento do observável, então precisamos fazer uso apenas de inferências metafísicas que são de menor magnitude do que os tipos de inferências que alguém poderia rejeitar, enquanto empirista.

Como uma ilustração da noção de "magnitude" nesse contexto, considere um duelo que é familiar para boa parte da filosofia da ciência contemporânea: entre defensores das chamadas abordagens humeanas ou neo-humeanas das leis da natureza, que eles veem como metafisicamente inocentes ou inobjetáveis, e defensores de posições metafísicas "mais pesadas", frequentemente descritas como aristotélicas ou neo-aristotélicas. As abordagens humeanas descrevem as leis simplesmente como (certas) regularidades; nada além é exigido a título de descrição metafísica. Mas isso é enganoso, porque as regularidades no mundo não são coisas triviais, metafisicamente falando. Uma regularidade não é tipicamente algo que possa ser observada, e a maioria delas é inobservável. São padrões de instanciação, de comportamento, etc., que são exemplificados no mundo sem exceção, no passado, presente e futuro. Como tais, são coisas substantivas de um ponto de vista ontológico. Além disso, negar que as leis incorporem os ingredientes ontológicos sugeridos por algumas visões neo-aristotélicas, como formas de necessidade de re ou propriedades inerentemente modais (por exemplo, as disposicionais), exige que se entre em debates metafísicos. Mas devemos ser justos sobre isso: tanto quanto a metafísica está envolvida nas afirmações sobre regularidades e na negação de uma ontologia adicional, a metafísica humeana exige menos ingredientes e, portanto, pode ser vista como menos pesada,

Principia 21(2): 189-207 (2017). 
metafisicamente falando. Mesmo assim, ela exige o suporte de inferências metafísicas.

Essa inevitabilidade da inferência metafísica, mesmo admitindo que as magnitudes da metafísica envolvida sejam menores em comparação com outros casos, também é uma característica da investigação científica a respeito de objetos, eventos, processos e propriedades que são observados. Aqueles que são atraídos para o empirismo costumam ser cautelosos com pressupostos e inferências metafísicas nas descrições da prática e do conhecimento científico, mas, como agora vou argumentar de maneira mais detalhada, eles não podem evitar se envolver em pelo menos alguma metafísica. Se essa tese parece surpreendente, especialmente em relação à experiência - seria compreensível que pareça assim para empiristas empenhados — isso é apenas porque as suposições e inferências relevantes estão frequentemente bem escondidas, ou tomadas como certas, de tal forma que não atraem atenção e, assim, não conseguimos notá-las como características da prática científica e do conhecimento em geral. A fim de tornar explícitas as inferências metafísicas relevantes e assim dar-lhes visibilidade, mesmo em concepções nas quais o conhecimento científico só vai até o observável, vamos enumerar algumas das maneiras muitas vezes ocultas pelas quais as inferências metafísicas entram no domínio da experiência.

Primeiro, da mesma maneira que sugeri há pouco que devemos prestar a devida atenção ao que são as regularidades precisamente, para não subestimar o seu peso ontológico ou metafísico nos debates sobre as leis da natureza, vamos prestar a devida atenção à questão sobre o que são os observáveis, precisamente. Considerei de passagem acima formas especialmente fortes de empirismo, como o fenomenalismo e o idealismo. Essas posições são especialmente fortes no sentido de que elas são extraordinariamente rigorosas sobre o que conta como entrando no escopo legítimo do conhecimento, tão rigorosas que negam a existência de um mundo exterior, um mundo que é independente da cognição humana a seu respeito, mas que é, ainda assim, um assunto de cognição humana. Esse tipo de negação, entretanto, não é o que a maioria dos empiristas contemporâneos tem em mente quando fala de um mundo de observáveis que está sujeito à experiência e à investigação científica. Em vez disso, eles têm em mente um mundo que é independente de nós, e eles afirmam que podemos experimentá-lo e conhecê-lo. Em virtude disso, formas de empirismo mais contemporâneas e menos radicais geram epistemologias da ciência segundo as quais a evidência empírica produz boas razões para acreditar em ao menos algumas proposições sobre coisas observáveis cuja existência não depende das sensações ou pensamentos humanos.

Essa concepção empirista menos radical de crenças sobre observáveis é tão comum — é amplamente compartilhada mesmo por aqueles que não são amigáveis ao empirismo em primeiro lugar — que é muito fácil tomá-la como certa e falhar completamente em examiná-la. Contudo, com mais reflexão, essa compreensão de nosso 
conhecimento de observáveis, bem como o próprio conhecimento de observáveis, exige inferências metafísicas. Ao descrever uma ontologia de coisas além daquilo que o fenomenalista ou o idealista aceitaria, fica claro após certa reflexão que nem todas as experiências são indicativas de verdades, em qualquer maneira direta. As ligações entre a experiência e as determinações de fatos sobre observáveis são muitas vezes complexas. Sem dúvida, há casos em que a experiência produz esses fatos de maneira razoavelmente imediata, como na formação de diversas crenças perceptivas simples. Por outro lado, é frequente que tais conexões entre experiência e verdades sobre observáveis sejam mais complicadas. Considere, por exemplo, cenários perceptivos mais interessantes em que os objetos aparecem de maneiras distorcidas em (ou através de) meios com propriedades ópticas que diferem das do ar, como quando um canudo aparece torto em um copo de água mesmo que ele seja, na verdade, reto. A relação muitas vezes complexa entre evidências experienciais e verdades sobre observáveis exige que nós distingamos experiências verídicas e enganosas sistematicamente, e eu (agora sim) sugiro que isso requer inferências metafísicas.

Em contextos científicos, nossa confiança em inferências metafísicas a respeito de fatos sobre observáveis é revelada pela prática comum de invocar teorias e modelos que descrevem os fenômenos subjacentes a esses fatos. Fazemos isso por vários motivos. Um deles é que frequentemente trata-se de uma questão substantiva se as condições de observação são tais que podemos esperar ter experiências verídicas (como o caso simples do canudo atesta), e para determinar se temos as condições apropriadas para a experiência verídica não é incomum aplicar teorias e modelos que envolvam pressupostos e inferências metafísicas (como, por exemplo, teorias da óptica e modelos de fenômenos como reflexão, refração e difração). Em alguns casos, esse recurso à inferência metafísica é importante não apenas para lidar com preocupações a respeito de distorções ópticas de entidades verdadeiramente observáveis, mas também para lidar com experiências que são mais severamente enganadoras, sugerindo a existência de entidades que, de fato, não existem. ${ }^{4}$ Talvez você acredite ter visto o Curupira nas florestas brasileiras em várias ocasiões, mas uma investigação mais cuidadosa revela que o que você achou que eram avistamentos de Curupira eram na verdade coisas calculáveis: como os efeitos ópticos das sombras e a luz filtrada pelas árvores de maneiras interessantes.

Esse pensamento sobre o que é necessário para promover uma experiência verídica baseia-se no truísmo de que nem toda a experiência é criada de maneira igual. Ele se aplica não só no laboratório e no campo, mas na vida cotidiana, o que novamente ajuda a explicar por que é tão fácil tomar apelos à inferência metafísica como garantidos e considerá-los invisíveis nas discussões sobre conhecimento. Embora eu tenha argumentado que os debates tradicionais sobre se a metafísica é ou não parte da ciência são inconclusivos, espero ter mostrado que, uma vez esclarecida a natureza da inferência metafísica, como fiz aqui, vemos que elas são claramente

Principia 21(2): 189-207 (2017). 
indispensáveis mesmo para descrições científicas de observáveis, para diferenciar as boas observações das ruins e, dentre as boas, as melhores. É certo que, como mencionei, existem algumas formas de empirismo que podem escapar desse diagnóstico e evitar completamente a inferência metafísica, a saber, versões do empirismo que não permitem de forma alguma afirmações sobre um mundo ou uma realidade externa. Considere, por exemplo, um fenomenalismo estrito do momento presente, segundo o qual a extensão do conhecimento de alguém é esgotada por suas sensações atuais. Ao se restringir tão severamente, é plausível que esse tipo de visão não recorra à inferência metafísica, e isso aponta para uma maneira pela qual os debates tradicionais sobre a metafísica que permeia a ciência são inconclusivos, desde que tais posições radicais estejam na mesa. É justo dizer, no entanto, que esses tipos de posição não têm sido consideradas opções vivas em discussões de conhecimento científico há quase um século. ${ }^{5}$

Vale ressaltar que ao esboçar a ideia de um espectro de inferências metafísicas de magnitudes menores e maiores não considero ter dito qualquer coisa que, após alguma reflexão, pareça excessivamente surpreendente. Tive como objetivo a tarefa modesta de articular a importância dessas inferências para a integridade do nosso conhecimento de fenômenos observáveis ao iluminar como alguns graus menores delas são muitas vezes necessários para derivar conhecimento a partir da experiência, especialmente em contextos científicos. Na verdade, embora às vezes sejam subestimadas nos debates contemporâneos entre realistas científicos e empiristas antirrealistas bem como em outros debates entre realistas e antirrealistas de um lado e metafísicos incondicionais do outro - sugestões semelhantes apareceram em algumas filosofias da ciência importantes e influentes do século passado. Por exemplo, Wilfrid Sellars (1956) ficou famoso por argumentar contra o "mito do dado". Nenhum estado cognitivo (o que inclui estados experienciais), ele sustentou, pode servir por si mesmo como base a partir da qual fatos sobre o mundo são simplesmente "lidos". Norwood Russell Hanson (1958, cap.1), Paul Feyerabend (1975) e Kuhn defenderam variações sobre o tema do carregamento teórico da observação, segundo o qual crenças teóricas prévias desempenham um papel substancial na formatação da experiência na ciência e em outros contextos, assim como nossas descrições e interpretações delas.

É claro, nada do que eu disse até agora depende da noção de que todas as experiências são carregadas de teoria. Talvez algumas não sejam, mas se o meu argumento é convincente, então muitas são. E as ciências incluem uma série de contextos nos quais deveríamos esperar que sejam. Essa é mais uma razão pela qual é adequado que agora tenhamos nos movido para além da associação estrita, predominante durante a era do empirismo lógico, dos chamados termos "teóricos" com termos que são usados para rotular o que os realistas reconheceriam como entidades supostamente inobserváveis, em distinção aos termos para entidades observáveis, que são, nessa visão, não teóricas. É mais comum agora simplesmente falar em termos para observáveis e ter- 
mos para inobserváveis. E isso só é apropriado se, como sugeri, nosso conhecimento do mundo observável das ciências, por meio da experiência, é igualmente teórico.

\section{Mais duas, da história da filosofia da ciência}

Há dois outros sentidos, intimamente ligados entre si e ligados com a ideia do carregamento teórico, nas quais inferências metafísicas são inevitáveis em grande parte de nossa experiência de entidades observáveis envolvidas em fenômenos cientificamente interessantes. Acredito que, de maneira parecida com as sugestões da seção anterior, a primeira dessas considerações adicionais não deve se mostrar muito controversa após a reflexão, enquanto a segunda, em virtude de ser um pouco mais especulativa, pode ser mais provocativa. Embora ambas tenham raízes na filosofia da ciência de meados do século $X X$, a segunda, em particular, ultrapassa essa história recente. Em conclusão, consideremos ambas as sugestões por sua vez.

Ao fazer os tipos de juízos que são necessários para concentrar a experiência na construção do conhecimento científico sobre o mundo observável — para distinguir a experiência verídica e não verídica, para determinar a qualidade das observações, e para descrever e interpretar isso tudo - é inevitável classificar aquilo de que temos experiência (diversos objetos, eventos, processos e propriedades) em categorias para fins descritivos. Isso por si só é uma verdade banal: seria impossível fazer qualquer um dos juízos que acabamos de enumerar a menos que estejamos dispostos e sejamos capazes de "esculpir" o mundo em categorias observáveis de coisas - de modo que possamos nos comunicar uns com os outros sobre essas coisas e assim coordenar as atividades científicas e não científicas. Em outras palavras, devemos taxonomizar o conteúdo da experiência para que ela possa funcionar como evidência empírica e conhecimento. Além de taxonomias compartilhadas, uma comunidade científica requer princípios compartilhados, de modo a permitir o bom funcionamento da sua prática compartilhada, em questões metodológicas sobre, por exemplo, como extrapolar as observações de maneiras epistemologicamente sensatas, de modo a formular generalizações sobre os fenômenos relevantes e sobre como esses dados devem ser usados para testar hipóteses e teorias e confirmá-las. Tudo isso deve ser compartilhado se uma comunidade científica deve funcionar de forma coerente.

Qual é a fonte desse pano de fundo compartilhado? Autores como Ludwig Fleck (1935[1979]), Michael Polanyi (1966[2009]) e Kuhn responderam a essa questão, e o que há de comum entre suas respostas é amplamente aceito atualmente. Esta mescla de princípios taxonômicos e metodológicos, que funciona como uma pré-condição necessária para o trabalho científico (mesmo quando o conteúdo do conhecimento associado é restrito ao mundo observável), não pode ser adquirida simplesmente ao ter experiências em qualquer sentido muito estreito. Os compromissos de fundo

Principia 21(2): 189-207 (2017). 
assumidos por uma comunidade científica são inculcados por meio de formas de treinamento altamente específicas nas quais os princípios relevantes são absorvidos, permitindo uma prática científica comum. Isso é parte do que Kuhn tinha em mente quando falou de paradigmas que governavam o trabalho científico. E também do que ele e Polanyi tinham em mente quando descreveram muitos desses compromissos como "tácitos", na medida em que não podem ser formulados como proposições para que alguém acredite ou como conjuntos de instruções para que alguém siga. Van Fraassen (2002, p.130) expressa algo semelhante quando defende que as "tradições" compartilhadas subjacentes às práticas científicas não são "formuláveis como um texto". Os compromissos relevantes são muito mais próximos do que chamamos de saber-como do que do saber-que. Saber como experienciar o mundo é um precursor para derivar conhecimento da experiência. Essa dimensão a priori do pano de fundo é o que o torna metafísico no meu sentido, como explicado acima.

Tudo isso dito, em concordância com o que vejo contido de várias maneiras na história recente da filosofia da ciência, concluirei dando um passo adiante. Uma coisa é dizer que os compromissos de fundo são algo que nós, como agentes humanos, devemos trazer à experiência para produzir conhecimento. Outra coisa é dar um passo além e investigar sobre a natureza desse pano de fundo, concebido como algo que tem um papel explicativo sério na descrição de como as comunidades científicas geram conhecimento. O que é um conjunto de compromissos de fundo, uma coleção de saber-como, concebida como uma coisa à qual atribuímos os vários papéis explicativos aqui indicados? Pode-se considerar possível vislumbrar uma resposta a esta questão implícita nos escritos de muitos dos autores que acabei de invocar, mas nenhum deles é explícito da forma como eu penso que devemos ser. O que estamos chamando de "o pano de fundo" em qualquer contexto de prática científica é uma entidade inobservável de natureza complexa. É ao mesmo tempo cognitiva e heurística, como demonstrado em sua aplicação à experiência de cientistas, bem como social e culturalmente transmitida por meio de treinamento e aculturação. É algo que está subjacente à experiência e às muitas práticas científicas relevantes para a elaboração, descrição e interpretação das observações e as extrapolações a partir das quais caracterizamos o mundo observável.

Um momento atrás, descrevi esse último argumento para a inevitabilidade da inferência metafísica como mais "especulativo" do que aquele que veio antes. Isto é porque é justo questionar se o que descrevi como uma "coisa" intersubjetivamente cognitiva, heurística, social, culturalmente transmitida é devidamente descrita como uma entidade - ainda mais inobservável, parecida talvez com os supostos inobserváveis mais familiares (como partículas subatômicas e genes) comumente discutidos na filosofia da ciência. Para encerrar, então, motivarei essa especulação um pouquinho mais. Talvez estejamos muito acostumados com exemplos das ciências naturais; "o pano de fundo" aqui é algo que poderia se aproximar das perspectivas das ciên- 
cias humanas ou sociais, nas quais as entidades são muitas vezes complexas, e nas quais ter uma natureza complexa não sugere por si só que uma entidade suposta é irreal. Embora os compromissos de fundo não sejam, estritamente falando, observáveis, agora deve estar claro que eles são postulados por razões explicativas, para dar conta de uma série de características claramente observáveis da prática científica bem-sucedida. Ao fazê-lo, nos servimos, mais uma vez, da inferência metafísica. Não fazemos tão de leve. Teorizamos sobre o pano de fundo porque buscamos um entendimento do valor do conhecimento científico, e é difícil imaginar como certas características da prática científica poderiam ser explicadas de qualquer outra maneira.

Se o que precede foi atraente, temos mais uma razão para pensar que as inferências metafísicas são importantes para a nossa experiência do mundo observável das ciências. No processo de buscar entender como os compromissos classificatórios e metodológicos desempenham um papel na construção e avaliação da experiência, descobrimos que tais comprometimentos não são simplesmente "lidos" da experiência - e, ao teorizar sobre eles, parece plenamente adequado vê-los como entidades sociais complexas que servem como referenciais para a própria experiência. Eles são, ao que parece, suscetíveis de investigação por direito próprio. E assim, parece que mesmo aqueles que são atraídos para o empirismo têm razão para se envolver com uma pequena inferência metafísica, afinal. ${ }^{6}$

\section{Agradecimentos}

Eu gostaria de dedicar este trabalho aos muitos filósofos sul-americanos, com os quais apreciei o memorabilíssimo $X$ Simpósio Internacional Principia, em Florianópolis, sobre "A Construção da Experiência". Tenho especial gratidão a Ivan Ferreira da Cunha e Cezar Augusto Mortari por múltiplas gentilezas, e, ao Ivan, novamente, e ao Raoni Wohnrath Arroyo, pela incrível gentileza na tradução deste artigo.

\section{Referências}

Barnes, B.; Bloor, D.; Henry, J. 1996. Scientific Knowledge: A Sociological Analysis. Chicago: University of Chicago Press.

Callender, C. 2011. Philosophy of Science and Metaphysics. In: S. French; J. Saatsi (eds.) The Continuum Companion to the Philosophy of Science, pp.33-54. London: Continuum.

Chakravartty, A. 2017. Scientific Ontology: Integrating Naturalized Metaphysics and Voluntarist Epistemology. New York: Oxford University Press.

Feyerabend, P. 1975. Against Method. London: New Left Books.

Fleck, L. 1935[1979]. Genesis and Development of a Scientific Fact. Chicago: University of Chicago Press.

Principia 21(2): 189-207 (2017). 
Hanson, N. R. 1958. Patterns of Discovery: An Inquiry Into the Conceptual Foundations of Science. Cambridge: Cambridge University Press.

Kuhn, T. 1962[1970]. The Structure of Scientific Revolutions. Chicago: University of Chicago Press.

Marcum, J. A. 2005. Metaphysical Presuppositions and Scientific Practices: Reductionism and Organicism in Cancer Research. International Studies in the Philosophy of Science 19: 31-45.

Polanyi, M. 1966[2009]. The Tacit Dimension. Chicago: University of Chicago Press.

Sellars, W. 1956. Empiricism and the Philosophy of Mind. In H. Feigl; M. Scriven (eds.) Minnesota Studies in the Philosophy of Science, vol. I., pp.253-329. Minneapolis: University of Minnesota Press.

van Fraassen, B. C. 2002. The Empirical Stance. New Haven: Yale University Press.

ANJAN CHAKRAVARTTY

University of Notre Dame

chakravartty.1@nd.edu

ACCEPTED: 15/01/2018

\section{Notas}

${ }^{1}$ Seria imprudente afirmar que a moral do que se segue é aplicável a tudo o que se quer dizer com "experiência" na filosofia, embora com certeza seja aplicável muito além dos casos que considerarei aqui.

${ }^{2}$ Para uma tentativa de lidar com todo o alcance dessas implicações, cf. Chakravartty 2017.

${ }^{3}$ Reconheço que a capacidade de persuasão dessa declaração a respeito da onipresença é ainda, neste estágio, uma nota promissória. Retornarei a este ponto na próxima seção.

${ }^{4}$ Nas discussões filosóficas sobre a experiência cotidiana, independentemente dos contextos científicos, questões semelhantes foram levantadas em conexão com fenômenos mentais, como ilusões, alucinações e sonhos.

${ }^{5}$ Este não é o lugar para explorar as razões pelas quais muitos chegaram à conclusão de que essas epistemologias são inadequadas e talvez até incoerentes. Para os presentes propósitos, é suficiente notar que nos últimos tempos, os filósofos empiristas da ciência ampliaram o alcance do que pode ser conhecido para além das impressões e ideias em direção a coisas observáveis no mundo.

${ }^{6}$ Tradução de Ivan Ferreira da Cunha e Raoni Wohnrath Arroyo

Principia 21(2): 189-207 (2017). 